\title{
Comparative study of students' Entrepreneurship Intentions with reference to North-India Region
}

\author{
Effulgence \\ Vol. 18, No. 2 \\ July - December, 2020 \\ Rukmini Devi Institute of Advanced Studies \\ E-mail : effulgence@rdias.ac.in, Website : www.rdias.ac.in \\ http://effulgence.rdias.ac.in/user/default.aspx \\ https://dx.doi.org/10.33601/effulgence.rdias/v18/i2/2020/58-64
}

\author{
Prof. (Dr.) Tusshar Mahajan ${ }^{1} \bowtie$ \\ Mr. Tanmay Mahajan ${ }^{2}$
}

\begin{abstract}
Entrepreneurship is a crucial factor for economic revolution. It also enhances societal development. There are so many factors which trigger Entrepreneurship Intention but considering students' viewpoint, choosing entrepreneurship as career is not an easy step due to related risk and also because of societal pressure in developing countries like India. Students' Entrepreneurship Intentions are also governed by so many factors.

The present study is a comparative study of Entrepreneurship Intentions of students of selected universities of North-India. The research study analyzed factors of Entrepreneurship Intentions and compared students in terms of Risk-taking Ability Factor of Entrepreneurship Intentions with respect to Gender, University Type and Area Type. In summarized way, the research study showed that with reference to Risk-taking Ability, Government University Male students were found to have more Entrepreneurship Intentions than Private University Male students.
\end{abstract}

Keywords: Entrepreneurship Intentions, North-India, Government University, Private University.

\section{INTRODUCTION}

ntrepreneurship leads to employment
generation and in turn supports growth of economy and also development of society. It empowers society and also augmenting productivity of manpower. Policymakers, academic institutions and different organizational bodies are giving importance on entrepreneurship development in order to offer support for the budding entrepreneurs. Students can bring radical change to society and economy through entrepreneurship. Entrepreneurship plays an important role in developing countries, as it is considered as the engine of growth.

Entrepreneurship activities help for economic growth and in turn support societal development

1. Professor, PGDM, Institute of Management Studies, Ghaziabad, tushar.mahajan8@gmail.com

2. B. Tech. Student, Vellore Institute of Technology-Chennai Campus, tanmay.mahajan13@gmail.com 
and decline in unemployment. Young people can play an important role in this direction. Henry (2003) found that many business graduates are unable to get a job, so there is need to enhance students' entrepreneurship intentions and skills to start their own business.

In case of developing countries like India, there is need of conducting research to examine students' entrepreneurship intentions so that they can contribute for economic development of nation. The present research work focused on identifying factors affecting Entrepreneurship Intentions of students of selected universities of North India and analyzed effect of demographic variables on Risk-taking Ability factor of entrepreneurship intentions of students.

\section{LITERATURE REVIEW}

It has been observed that now students are also opting entrepreneurship-venture as substitute career opportunity (Gelard and Saleh, 2011). Individuals go for entrepreneurship owing to the utility derived from entrepreneurship as a career alternative. Individuals elect entrepreneurship because they expect to get better benefits in comparison to formal employment (Douglas and Shepherd, 2000). Zimmerer and Scarborough (2003) found that entrepreneurship is a significant contributor for enhancing economic growth. Kuratko and Hodgetts (2004) reported that entrepreneurship creates employment prospects and brings technology related transformations.

Venesaar and Loomets (2006) studied students' entrepreneurial intentions at Tallinn University and related factors along with role of university towards it. Study indicated that in general significant number of students want to go for entrepreneurship but majority of them postponed this idea to future time due to various reasons. Narendra (2006) did research to study entrepreneurial intentions of Indian university students and showed that factors like: leading people, autonomy, implementing innovations, determination, and tendency to accept challenges support entrepreneurial intentions.

Friedman and Triburelle (2009) studied effect of gender on entrepreneurship intentions of management students. They reported that male students were found to exhibit more entrepreneurial intention than female students. Maalu et al. (2010) reported that entrepreneurial aptitude is supported by factors viz. self-responsibility; utilizing own skills; achievement tendency; freedom; opportunity of making and implementing decisions; learning attitude; financial independence; accepting challenges; peaceful life; work-life balance; becoming powerful person etc.

Entrepreneurs possess risk-taking attitude and they are ready to tolerate initial losses with a motive to gain profit subsequently (Forlani and Mullins, 2000). It has been reported that the tendency to take risks distinguishes entrepreneurs and non-entrepreneurs (Elston and David, 2007). Achchuthan and Nimalathasan (2012) studied entrepreneurship intentions of management students of Sri Lanka. They reported that Self-employment Desirability and Risk-Tolerance influence intentions of students toward the entrepreneurship.

\section{RESEARCH METHODOLOGY}

The research study analyzed Students' Entrepreneurship Intentions with special reference to selected North Indian Universities. In this regard, research objectives are listed as below:

1. To examine driving factors for Entrepreneurship Intentions of students.

2. To compare Risk-taking Ability Factor of Entrepreneurship Intentions of students with respect to Gender, University Type and Area Type.

Self-designed questionnaire using 5-point Likert Scale was administered for data collection. Owing to this, for analyzing reliability, Cronbach alpha was 
determined to be 0.82. Respondents were management and engineering students (Male and Female students) of Government and Private Universities from Metropolitan area \& NonMetropolitan area. For the study, after validating, final sample size of 400 was used. Data analysis was carried out through statistical tools Factor Analysis,
t-Test and ANOVA using SPSS 21.

\section{Results of the Study}

Factor-Analysis was applied to questionnaire items related to Entrepreneurship Intentions. Factor analysis resulted in four factors, as below:

\section{Table 1: Rotated Component Matrix}

\begin{tabular}{|c|c|c|c|c|}
\hline & \multicolumn{4}{|c|}{ Component } \\
\hline & 1 & 2 & 3 & 4 \\
\hline Q3 & .734 & & & \\
\hline Q5 & .663 & & & \\
\hline Q1 & .663 & & & \\
\hline Q4 & .633 & & & \\
\hline Q9 & .581 & & & \\
\hline Q7 & .546 & & & \\
\hline Q8 & .480 & & & \\
\hline Q14 & .434 & & & \\
\hline Q22 & & .691 & & \\
\hline Q21 & & .665 & & \\
\hline Q20 & & .594 & & \\
\hline Q24 & & .589 & & \\
\hline Q23 & & .584 & & \\
\hline Q25 & & .518 & & \\
\hline Q16 & & & .681 & \\
\hline Q15 & & & .624 & \\
\hline Q18 & & & .619 & \\
\hline Q19 & & & .598 & \\
\hline Q17 & & & .583 & \\
\hline Q2 & & & .468 & \\
\hline Q11 & & & & .650 \\
\hline Q10 & & & & .629 \\
\hline Q13 & & & & .626 \\
\hline Q12 & & & & .556 \\
\hline Q6 & .449 & & & .463 \\
\hline Q26 & & .423 & & .449 \\
\hline
\end{tabular}

Extraction Method: Principal Component Analysis.

Rotation Method: Varimax with Kaiser Normalization ${ }^{a}$

a. Rotation converged in 6 iterations. 
Extracted four factors of Entrepreneurship Intentions of students are: - Factor 1: Autonomy Factor; Factor 2: Need for Achievement Factor; Factor 3: Confidence in Support-system Factor; and Factor 4: Risk-Taking Ability Factor. The present study is based on Risk-taking Ability Factor of Entrepreneurship Intentions and the results, derived using ANOVA and t-test, are presented as follows:

Part 1: Hypothesis testing through application of ANOVA

$\mathbf{H}_{00}$ : Gender does not interact in terms of Risk-taking Ability Factor of Entrepreneurship Intention.

The null hypothesis is accepted $(\mathrm{F}=1.897, \mathrm{p}=.169)$.

$\mathbf{H}_{02}$ : University Type does not interact in terms of Risk-taking Ability Factor of Entrepreneurship Intention.

The null hypothesis is accepted $(\mathrm{F}=.872, \mathrm{p}=.351)$.

$\mathbf{H}_{03}$ : Area Type does not interact in terms of Risktaking Ability Factor of Entrepreneurship Intention.

The null hypothesis is accepted $(\mathrm{F}=.479, \mathrm{p}=.489)$.
$\mathbf{H}_{04}$ : Gender and University type do not interact in terms of Risk-taking Ability Factor of Entrepreneurship Intention.

The null hypothesis is accepted $(F=.895, p=.345)$.

$\mathbf{H}^{05}$ : Gender and Area Type do not interact in terms of Risk-taking Ability Factor of Entrepreneurship Intention.

The null hypothesis is accepted $(\mathrm{F}=2.840, \mathrm{p}=.093)$.

$\mathbf{H}_{06}$ : University type and Area type do not interact in terms of Risk-taking Ability Factor of Entrepreneurship Intention.

The null hypothesis is accepted $(F=.012, p=.913)$.

$\mathbf{H}_{07}$ : Gender, University type and Area type do not interact in terms of Risk-taking Ability Factor of Entrepreneurship Intention.

The null hypothesis is accepted $(\mathrm{F}=1.786, \mathrm{p}=\mathbf{. 1 8 2})$. Above results are presented in tabular form as below:

Table 2: Anova

\begin{tabular}{|c|c|c|c|c|c|}
\hline \multicolumn{6}{|c|}{ Dependent Variable: RISK_TAKING ABILITY } \\
\hline Source & $\begin{array}{l}\text { Type III Sum } \\
\text { of Squares }\end{array}$ & Df & $\begin{array}{l}\text { Mean } \\
\text { Square }\end{array}$ & F & Sig. \\
\hline Corrected Model & $104.648^{\mathrm{a}}$ & 7 & 14.950 & 1.219 & .291 \\
\hline Intercept & 174101.996 & 1 & 174101.996 & 14193.309 & .000 \\
\hline GENDER & 23.267 & 1 & 23.267 & 1.897 & .169 \\
\hline UNIV_TYPE & 10.698 & 1 & 10.698 & .872 & .351 \\
\hline AREA & 5.871 & 1 & 5.871 & .479 & .489 \\
\hline GENDER * UNIV_TYPE & 10.975 & 1 & 10.975 & .895 & .345 \\
\hline GENDER * AREA & 34.842 & 1 & 34.842 & 2.840 & .093 \\
\hline UNIV_TYPE * AREA & .146 & 1 & .146 & .012 & .913 \\
\hline $\begin{array}{l}\text { GENDER * UNIV_TYPE * } \\
\text { AREA }\end{array}$ & 21.913 & 1 & 21.913 & 1.786 & .182 \\
\hline Error & 4808.462 & 392 & 12.266 & & \\
\hline Total & 192662.000 & 400 & & & \\
\hline Corrected Total & 4913.110 & 399 & & & \\
\hline
\end{tabular}

a. R Squared $=.021($ Adjusted R Squared $=.004)$ 
Part 2: Hypothesis testing through application of $t-$ test

$\mathbf{H}_{08}$ : Male students do not differ from Female students in terms of Risk-taking Ability Factor of Entrepreneurship Intention.

$$
\overline{\mathrm{X}}_{\text {MAle }}=21.84 \frac{\overline{\mathrm{X}}_{\text {MAle }} \approx \overline{\mathrm{X}}_{\text {Female }}}{\overline{\mathrm{X}}_{\text {Female }}=21.49}
$$

The null hypothesis is accepted $(t=.997, \mathrm{p}=.319)$.

$\mathbf{H}_{09}$ : Private university students do not differ from Government university students in terms of Risktaking Ability Factor of Entrepreneurship Intention.

$$
\overline{\mathrm{X}}_{\text {PRIV.UnIV. }}=21.53 \frac{\overline{\mathrm{X}}_{\text {PRIV.UnIV. }} \approx \overline{\mathrm{X}}_{\text {Govt.UnIV. }}}{\overline{\mathrm{X}}_{\text {Govt.Univ. }}=21.80}
$$

The null hypothesis is accepted $(t=-.769, \mathrm{p}=.442)$.

$\mathbf{H}_{10}$ : Metropolitan area students do not differ from Non-Metropolitan area students in terms of Risktaking Ability Factor of Entrepreneurship Intention.

$$
\overline{\mathrm{x}}_{\text {Metropoltan }}=21.63 \frac{\overline{\mathrm{x}}_{\text {NON-MEtropolttan }} \approx \overline{\mathrm{x}}_{\text {MEtropoltan }}}{\overline{\mathrm{x}}_{\text {NON-METROPOLITAN }}=21.71}
$$

The null hypothesis is accepted $(t=-.228, p=.820)$.

$\mathbf{H}_{11}$ : Metropolitan Male students do not differ from Non-Metropolitan Male students in terms of Risktaking Ability Factor of Entrepreneurship Intention.

$$
\overline{\mathrm{x}}_{\text {Metro.Male }}=22.16 \frac{\overline{\mathrm{X}}_{\text {Metro.male }} \approx \overline{\mathrm{X}}_{\text {NON-Metro.Male }}}{\overline{\mathrm{X}}_{\text {NON-METro.MAle }}=21.52}
$$

The null hypothesis is accepted $(t=1.215, p=.226)$.

$\mathbf{H}_{12}$ : Metropolitan Female students do not differ from Non-Metropolitan Female students in terms of Risktaking Ability Factor of Entrepreneurship Intention.

$$
\overline{\mathrm{X}}_{\text {Metro.Female }}=21.09 \frac{\overline{\mathrm{X}}_{\text {NON-Metro.FeMale }} \approx \overline{\mathrm{X}}}{\text { Metro.FeMale }}
$$

The null hypothesis is accepted $(t=-1.737, p=.084)$.

$\mathbf{H}_{13}$ : Private University Male students do not differ from Government University Male students in terms of Risk-taking Ability Factor of Entrepreneurship Intention.

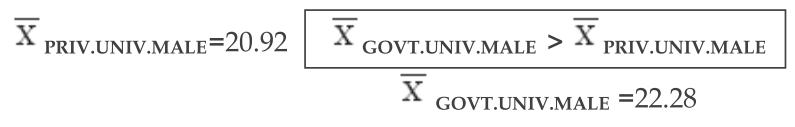

The null hypothesis is rejected $(t=-2.515, p=.013)$.

Hence, Private University Male students differ significantly from Government University Male students in terms of Risk-taking Ability Factor of Entrepreneurship Intention. Government University Male students were found to be more inclined towards Risk-taking Ability Factor than Private University Male students. It indicates that Government University Male students were found to have more Entrepreneurship Intention in terms of Risk-taking Ability.

$\mathbf{H}_{14}$ : Private University Female students do not differ from Government University Female students in terms of Risk-taking Ability Factor of Entrepreneurship Intention.

$$
\overline{\mathrm{x}}_{\text {PRIV.UNIV.FEMALE }}=21.55 \frac{\overline{\mathrm{X}}_{\text {PRIV.UNIV.FEMALE }} \approx \overline{\mathrm{X}}_{\text {GOVT.UNIV.FEMALE }}}{\overline{\mathrm{X}}_{\text {GOVT.UNIV.FEMAlE }}=21.64}
$$

The null hypothesis is accepted $(t=.159, p=.874)$.

$\mathbf{H}_{15}$ : Private University Male students do not differ from Private University Female students in terms of Risk-taking Ability Factor of Entrepreneurship Intention.

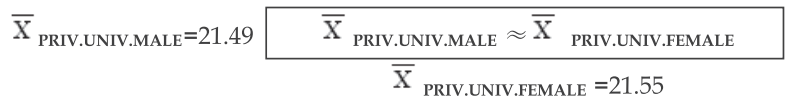

The null hypothesis is accepted $(t=-.101, p=.920)$.

$\mathbf{H}_{16}$ : Government University Male students do not differ from Government University Female students in terms of Risk-taking Ability Factor of Entrepreneurship Intention. 


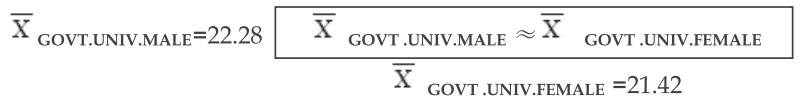

The null hypothesis is accepted $(t=-1.837, p=.068)$.

\section{CONCLUSIONS \& RECOMMENDATIONS}

The research study analyzed four factors of Entrepreneurship Intentions and compared students in terms of Risk-taking Ability Factor of Entrepreneurship Intentions of students of selected universities of North-India with respect to Gender, University Type and Area Type. Results of the study showed that Private University Male students differ significantly from Government University Male students in terms of Risk-taking Ability Factor of Entrepreneurship Intention. Government University Male students were found to have more Risk-taking Ability than Private University Male students, representing that Government University Male students are having more Entrepreneurship Intentions in terms of Risk-taking Ability. Hence it can be concluded that in general with reference to Risk-taking Ability, Government University Male students were found to have more Entrepreneurship Intentions.

It was observed during the study that in comparison to Government Universities, placement cell for students is functioning better in Private Universities. The research study implied that Government universities/institutions and Government bodies should take care of establishment and effective functioning of Entrepreneurship Development Cell (EDC) along with policy-formulation to help and guide Government University Male students towards Entrepreneurship.

\section{REFERENCES}

Achchuthan, S. and Nimalathasan, B. (2012). Level of entrepreneurial intention of the management undergraduates in the Universityof Jaffna, Sri Lanka: Scholars and undergraduates perspective. South Asian Academic Research Journals, 2(10) :
$24-42$

Douglas, E. J. and Shepherd, D. A. (2000). Entrepreneurship as a Utility-Maximizing Response. Journal of Business Venturing, pp231-251.

Elston, J.A. and David B. A. (2007). The role of risk in entrepreneurial behavior. Entrepreneurship: The Engine of Growth, Volumes 1-3 Edited by Maria Minniti, Praeger, London.

Forlani, D. and Mullins, J.W. (2000). Perceived risks and choices in entrepreneurs new venture decisions. Journal of Business Venturing, 15 (4), 305-322.

Friedman, E. H. and Triburelle, E. (2009). Examining a model of Entrepreneurial Intention among Malaysians. European Journal of Scientific Research, 3(2), 365-373.

Gelard P. and Saleh, E. K. (2011). Impact of some contextual factors on entrepreneurial intentions of university students. Journal of Business management, 5(26) 10707 - 10717.

Henry, B. (2003). Entrepreneurship Education In Kenya: A Reality or Plodding On? The First International Entrepreneurship Conference, 2324 April, 2003 Kenya.

Kuratko, D. F. and Hodgetts, R. M., (2004). Entrepreneurship: Theory, Process and Practice. Ohio, US, Thomson Learning.

Maalu, J., Stephen M. and Peterson O. M., (2010). A Survey of Personal Goals and Perceptions of Entrepreneurial Ability Among Students at the School Business,University of Nairobi. African Journal of Business \& Management Vol. 1

Narendra, (2006). Intention for Entrepreneurship among Students in India. The Journal of Entrepreneurship, Sage Journals, Vol 15, Issue 2, 2006.

Venesaar, U. and Loomets, P. (2006). The Role of Entrepreneurship in Economic Development and Implications for SME Policy in Estonia 1, Tallinn University of Technology, School of Economics and Business Administration, Estonia, Paper presented to the 14th Nordic Conference on Small Business Research, May 11-13, 2006, Stockholm, Sweden. 
Zimmerer, T. W. and Scarborough, N. M. (2003). Effective Small Business Management: An Entrepreneurial Approach. Upper Saddle River, NJ, Prentice Hall. 